\title{
TERAPI LATIHAN PASCACEDERA BAHU
}

\author{
Oleh: BM. Wara Kushartanti
}

Dosen FIK Universitas Negeri Yogyakarta

\section{Abstrak}

Cedera merupakan masalah yang sulit dihindari oleh olahragawan, baik di dalam kompetisi maupun di saat latihan. Beberapa kasus, cedera membuat seorang olahragawan terpaksa harus pensiun dini dari dunia olahraga prestasi. Cedera diakibatkan oleh kekuatan luar yang menimpa tubuh, melebihi daya tahan jaringan tubuh. Cedera bisa mengenai otot dan tendon, sendi dan ligamen, tulang, serta saraf.

Berbagai model terapi latihan untuk rehabilitasi cedera sudah diteliti. Model Terapi Latihan untuk cedera bahu dan lengan telah banyak diteliti dan terbukti bermanfaat dalam memulihkan cedera, baik secara subjektif maupun objektif. komponen dasar terapi latihan meliputi latihan fleksibilitas dan ROM, latihan kekuatan dan daya tahan otot, serta latihan proprioseptif, koordinasi, dan kelincahan.

Hasil Latihan dapat diketahui adanya peningkatan fleksibilitas atau Range of Movement (ROM), kekuatan, dan daya tahan otot. Untuk unsur kekuatan dapat dinilai dari kemampuannya melawan beban, baik mendorong, menarik, mengangkat, maupun menekan. Untuk daya tahan otot dapat dinilai dari kemampuannya melakukan usaha secara berulang-ulang, sedangkan untuk fleksibilitas dinilai dari kemampuannya menusuri kisaran gerak sendi. Besarnya kisaran gerak sendi pada saat tidak cedera dapat menjadi target hasil latihan, dan secara rinci tersaji sebagai berikut: (1) fleksi ke depan: 0 180 derajat, (2) ekstensi: 0 - 70 derajat, dan (3) adduksi: $0-45$ derajat

Kata kunci: Cedera, Terapi Latihan 
Prevalensi cedera saat ini cukup besar dan sebagian besar penyembuhannya tidak sempurna, sehingga ada kecenderungan untuk mengalami cedera ulangan/ kambuhan. Pada beberapa kasus, cedera membuat seorang olahragawan terpaksa harus pensiun dini dari dunia olahraga prestasi. Petenis Angelique Wijaya adalah salah satu contolkkasus berhentinya karir olahragawan akibat cedera yang tidak dapat sembuh sempurna. Di Amerika, kira-kira $20 \%$ anak-anak dan remaja yang berpartisipasi dalam olahraga mengalami cedera setiap tahunnya. Satu dari empat kasus cedera yang terjadi merupakan cedera yang serius (Konin, 2009). Di KONI DIY selama pelatda PON XII terlihat bahwa dari 98 kasus cedera yang ditangani, 72 kasus $(73,5 \%)$ diantaranya merupakan cedera kambuhan akibat penyembuhan cedera lama yang tidak sempurna (Litbang KONI DIY, 2008).

Di sisi lain, berbagai model terapi latihan untuk rehabilitasi cedera sudah diteliti. Model terapi latihan untuk cedera bahu dan lengan telah banyak diteliti dan terbukti bermanfaat dalam memulihkan cedera baik secara subjektif maupun objektif. Tekanan yang dihadapi pada pertandingan terkadang tidak bisa ditoleransi oleh tubuh. Jika kekuatan luar yang mengenai tubuh melebihi daya tahan jaringan tubuh, maka cedera akan terjadi. Cedera bisa mengenai otot dan tendon, sendi dan ligamen, tulang, saraf, dan lain sebagainya.

\section{PATOFISIOLOGI CEDERA}

Respon jaringan muskuloskeletal terhadap trauma menurut Kannus (2000) terdiri atas tiga fase, yaitu fase inflamasi akut, fase proliferatif, serta fase maturasi dan remodelling. Pada fase inflamasi akut, terjadi iskemia, gangguan metabolik, dan kerusakan membran sel karena proses peradangan, yang pada gilirannya ditandai dengan infiltrasi sel-sel inflamasi, edema jaringan, eksudasi fibrin, penebalan dinding kapiler, penutupan kapiler, dan kebocoran plasma. Segera setelah terjadi cedera, terjadi proses peradangan sebagai mekanisme pertahanan tubuh. Peradangan ditandai dengan panas, merah, bengkak, nyeri, dan hilangnya fungsi. Panas dan warna merah di tempat cedera disebabkan karena meningkatnya aliran darah dan metabolisme di tingkat sel. Pembengkaan akan terjadi di daerah cedera karena kerja agen-agen inflamasi dan tingginya konsentrasi protein, fibrinogen dan gamma globulin. Cairan akan mengikuti protein, keluar sel dengan cara 
osmosis, sehingga timbul bengkak. Rasa nyeri disebabkan oleh iritan kimiawi yang dilepaskan di tempat cedera. Nyeri juga terjadi akibat meningkatnya tekanan jaringan karena bengkak yang akan mempengaruhi reseptor saraf, dan menyebabkan nyeri (The Athlete Project, 2005).

Pada fase proliferatif, terjadi pembentukan faktor pembekuan fibrin dan proliferasi fibroblast, sel sinovial, dan kapiler. Sel-sel inflamasi menghilangkan jaringan yang rusak dengan fagositosis, dan fibroblast secara ekstensif memproduksi kolagen (pada awalnya adalah yang paling lemah, yaitu kolagen tipe 3, selanjutnya tipe 1) dan komponen matriks ekstraselular lainnya. Fase maturasi ditandai dengan berkurangnya kandungan air proteoglikan pada jaringan penyembuhan dan serabut kolagen tipe 1 akan kembali normal. Kira-kira 6 sampai 8 minggu sesudah cedera, serabut kolagen baru dapat menahan tekanan yang mendekati normal, meskipun maturasi tendon dan ligamen mungkin membutuhkan waktu lebih lama, bisa sampai 6-12 bulan.

\section{REHABILITASI CEDERA}

Menurut Houglum (2005), prinsip rehabilitasi harus memperhatikan prinsip-prinsip dasar sebagai berikut: (1) menghindari memperburuk keadaan, (2) waktu, (3) kepatuhan, (4) individualisasi, (5) beruntun secara spesifik, (6) intensitas, dan (7) total pasien. Pada penanganan rehabilitasi cedera, sangat penting untuk tidak memperburuk cedera. Terapi latihan, jika tidak dilaksanakan dengan benar potensial untuk membuat cedera lebih parah. Pengetahuan tentang bagaimana respon tubuh terhadap cedera menentukan dalam pemilihan latihan yang digunakan. Keterampilan dalam observasi respon pasien diperlukan untuk mengenali kapan dan seberapa jauh pengaruh program terapi latihan dapat memberi efek tanpa memperburuk cedera.

Prinsip terapi latihan dalam program rehabilitasi harus dimulai sesegera mungkin, tanpa memperburuk cedera. Semakin cepat pasien memulai porsi latihan, semakin cepat dapat kembali ke aktivitas sepenuhnya. Setelah cedera, istirahat memang diperlukan, namun demikian hasil penelitian menunjukkan bahwa terlalu banyak istirahat akan memperlambat pemulihan. Dikatakan bahwa imobilisasi seminggu pertama setelah cedera, 3\% - 4\% kekuatan otot berkurang setiap harinya. Beberapa studi menemukan bahwa laju pemulihan jauh lebih lam- 
bat daripada laju kehilangan kekuatan otot. Penemuan tersebut mengindikasikan pentingnya memulai prógram terapi latihan sesegera mungkin setelah kondisi memungkinkan. Tanpa kepatuhan pasien, program rehabilitasi tidak akan berhasil. Untuk memastikan kepatuhan, sangatlah penting untuk menginformasikan isi dan tujuan programm kepada pasien. Pasien akan lebih patuh jika pasien menyadari program yang diikutinya. Seringkali seseorang yang mengalami cedera merasa kehilangan kekuatan akibat cedera. Perasaan ini dapat mencegah kesuksesan program terapi latihan. Kepatuhan dalam hal ini berarti bahwa program dijalankan secara konsisten.

Masing-masing orang merespon cedera secara berbeda-beda, dan hal ini mempengaruhi program rehabilitasi yang harus diikuti. Perbedaan psikologis dan kimiawi mempengaruhi respon spesifik terhadap cedera. Sangat penting untuk menyadari bahwa meskipun suatu cedera kelihatannya sama, namun demikian perbedaan yang tidak terdeteksi dapat mengubah respon individu terhadap cedera. Urutan program rehabilitasi cedera, yaitu latihan fleksibilitas dan range of motion (ROM), latihan kekuatan dan daya tahan otot, serta latihan proprioseptif, koordinasi, dan kelincahan harus diikuti secara konsisten.

Intensitas terapi latihan harus memberi tantangan pasien dan daerah cedera, tetapi tidak boleh memperburuk cedera. Mengetahui kapan meningkatkan intensitas tanpa memperberat cedera membutuhkan observasi respon pasien dan pengetahuan tentang proses penyembuhan. Sebagai contoh, jika seorang pasien dapat dengan mudah memepertahankan keseimbangan satu kaki, buat program dengan aktivitas yang sama di atas permukaan yang tidak stabil, misalnya di atas trampolin mini. Jika di atas lantai terlalu mudah dan di atas trampolin terlalu sulit, maka pasien bisa melakukannya di atas lantai degan mata tertutup.

Sangatlah penting bagi pasien cedera untuk mempertahankan kebugaran pada daerah yang tidak terkena cedera. Hal ini berarti bahwa pasien harus menjaga sistem kardiovaskular pada tingkat sebelum cedera, mempertahankan ROM, kekuatan dan daya tahan otot, serta koordinasi pada anggota gerak dan sendi yang tidak cedera. Saat pasien cedera, fokus program rehabilitasi tidak hanya pada daerah cedera, tetapi juga pada seluruh tubuh. Menurut Viljoen (2000), rehabilitasi cedera meliputi pencegahan cedera, penilaian cedera, dan manajemen cedera. Pencegahan cedera terdiri atas tes sebelum partisipasi olahraga, intervensi secara individual, penilaian dan skrining teratur, latihan kekuatan dan 
kondisioning dengan benar, serta melibatkan ahli biomekanik olahraga. Idealnya tim medis meliputi dokter olahraga, fisioterapis, dan ahli biokinetik/biomekanik. Dokter olahraga bertugas mengkoordinasi dan menilai kondisi medis bersama dengan tim, menilai persiapan medis dalam even olahraga, mengkoordinasi rehabilitasi dan perkembangannya, mengatur dan menilai penggunaan alat-alat pelindung, manajemen cedera, mendiagnosis cedera, membuat keputusan klinis terkait beratnya cedera dan akibat yang ditimbulkannya, mengevaluasi kapan kembali bermain bersama dengan tim, serta mengedukasi olahragawan tentang zat-zat ergogenik dan daftar obat terlarang.

Fisioterapis olahraga bertugas mengevaluasi kondisi muskuloskeletal, mengawali segera rehabilitasi, manajemen cedera di lapangan bersama dokter olahraga, melakukan pembalutan pada cedera, mengevaluasi kesiapan kembali bertanding, bersama tim medis mengedukasi pemain tentang pencegahan cedera, dan menggunakan berbagai pendekatan multidisiplin dalam rehabilitasi. Ahli biokinetik/biomekanik bertugas membuat program kondisi fisik, sebelum, selama, dan sesudah pertandingan, mengevaluasi program rehabilitasi, memonitor dan mencegah overtraining, mengevaluasi kesiapan kembali bertanding, mengedukasi pemain tentang pencegahan dan pengobatan cedera, menggunakan pendekatan multidisiplin dalam rehabilitasi dan kondisioning, mengoreksi kondisi biomekanik yang tidak benar, merawat rekam medis dan data-data perkembangan pemain, serta memfasilitasi manajemen.

Penilaian cedera pada tahap awal dilakukan oleh dokter atau fisoterapis, dan kalau dibutuhkan bisa dilakukan pemeriksaan tambahan, seperti foto rongen, CT Scan, MRI, atau bahkan pembedahan jika diperlukan. Kunci kesuksesan rehabilitasi adalah diagnosis cedera yang tepat. Penilaian cedera meliputi riwayat cedera, observasi dan inspeksi, palpasi, penilaian fungsi otot, tes-tes khusus, seperti tes instabilitas ligamen. Tes tergantung pada lokasi, riwayat cedera, dan gejala yang timbul. Setelah dilakukan penilaian, disusun action plan, yang meliputi pengobatan segera, menentukan frekuensi dan durasi terapi, menentukan tujuan dan bagaimana memonitor kemajuan program, mengedukasi pasien, serta menentukan kriteria kapan bisa kembali bermain.

Manajemen cedera meliputi berbagai target yang bertujuan meningkatkan fungsi otot serta kondisi tubuh secara keseluruhan. Adapun komponen-komponen yang termasuk di dalamnya meliputi fleksibilitas, kekuatan dan daya tahan 
otot, power, kestabilan sendi, reaktivitas neuromuskular, kebugaran kardiovaskular, reedukasi gerak dan koordinasi, serta komponen biomotor spesifik lainnya.

\section{KOMPONEN DASAR TERAPI LATIHAN}

Program rehabilitasi mempunyai dua elemen dasar, yaitu terapi modalitas dan terapi latihan. Terapi modalitas digunakan untuk mengobati efek-efek akut cedera, seperti nyeri, bengkak, spasme, sedangkan terapi latihan sangat esensial dan merupakan faktor kritis bagi pasien untuk bisa kembali berpartisipasi dalam olahraga atau kembali ke aktivitas semula. Houglum (2005) menyebutkan bahwa komponen dasar terapi latihan meliputi latihan fleksibilitas dan ROM, latihan kekuatan dan daya tahan otot, serta latihan proprioseptif, koordinasi, dan kelincahan.

Fleksibilitas terkait dengan mobilitas otot dan kemampuan otot untuk memanjang. Jika otot mengalami imobilisasi selama periode waktu tertentu, ada kecenderungan untuk kehilangan fleksibilitas atau derajat mobilitas. Jika latihan peregangan disertakan dalam program kondisi fisik rutin, otot akan cenderung untuk mempertahankan fleksibilitas. ROM merujuk pada jumlah gerakan yang mungkin dilakukan oleh sebuah sendi. Sebagai contoh, normal ROM untuk abduksi sendi bahu adalah $180^{\circ}$. ROM dipengaruhi oleh fleksibilitas otot dan kelompok otot yang mengelilingi sendi. Jika fleksibilitas otot kurang, sendi tidak dapat melakukan ROM secara penuh. Selain itu ROM juga dipengaruhi beberapa faktor, seperti mobilitas kapsul sendi dan ligamen, fascia, serta kekuatan otot. Pencapaian fleksibilitas lebih awal dalam terapi latihan diperlukan karena parameter lain ditentukan oleh fleksibilitas daerah cedera dan efek dari proses penyembuhan. Jaringan yang sembuh dari cedera meninggalkan jaringan penyembuhan yang dapat meneyebabkan kontraktur. Selama masa penyembuhan, ada kesempatan emas untuk mengubah jaringan sikatrik tersebut.

Kekuatan otot merupakan kekuatan maksimum yang dapat dilakukan oleh otot, sedangkan daya tahan otot merupakan kemampuan otot untuk mempertahankan kekuatan submaksimal, baik dalam aktivitas statis maupun aktivitas repetitif. Kekuatan dan daya tahan otot saling mempengaruhi. Saat kekuatan otot meningkat, daya tahan juga meningkat dan sebaliknya. Lemahnya keseimbangan, proprioseptif, dan koordinasi, baik akibat cedera maupun kurangnya latihan keterampilan khusus, akan meningkatkan risiko cedera. Berbagai faktor berpengaruh 
terhadap proprioseptif, koordinasi, dan kelincahan. Di sisi lain, ketiga komponen ini akan mempengaruhi power otot, keterampilan eksekusi, dan penampilan secara umum. Untuk mengembangkan kemampuan proprioseptif dan koordinasi, fleksibilitas dan kekuatan otot harus sudah dicapai. Koordinasi dan kelincahan didasarkan pada fleksibilitas dalam menampilkan keterampilan melalui ROM yang memadai dan kekuatan, daya tahan, serta power otot untuk menampilkannya secara berulang, cepat, dan benar.

\section{CEDERA BAHU}

Bahu merupakan area unik, yang tersusun atas beberapa persendian, seperti sendi sternoclavicular, acromioclavicular, scapulothoracic, dan glenohumeral. Dalam melakukan fungsi mobilitas dan stabilitas, bahu didukung oleh sendi-sendi penyusunnya dan otot-otot di sekelilingnya, yang bekerja secara selaras supaya bahu dapat berfungsi normal. Hal mendasar yang mendukung fungsi sendi normal adalah stabilitas. Saat cedera terjadi, stabilitas sendi normal terganggu dan pemulihan sempurna bisa terancam, kecuali jika stabilitas dipertahankan. Stabilitas sendi dipengaruhi faktor statis dan dinamis. Stabilitas statis didukung oleh struktur yang membentuk sendi bahu, yaitu kapsul sendi, ligamen, dan labrum glenoid. Stabilitas dinamis merupakan tanggungjawab saraf dan otot, menyediakan input yang tepat dari reseptor aferen ke sistem saraf pusat. Saat ligamen mengalami cedera, reseptor aferen yang berlokasi di ligamen tersebut tidak bisa menyediakan input sensori yang adekuat. Hal ini membuat input neural lemah dan pada gilirannya menimbulkan respon otot yang tidak tepat. Hasilnya adalah berkurangnya stabilitas statis karena cedera itu sendiri dan ketidakstabilan dinamis disebabkan oleh kerusakan reseptor aferen. Ketidakstabilan dinamis terjadi jika otot di sekeliling bahu tidak seimbang. Jika kelompok otot agonis dan antagonis tidak seimbang, otot-otot tersebut kehilangan kontrol proprioseptif dan kinestetik, sehingga timbul ketidakstabilan dinamis. Ketidakseimbangan otot, jika tidak dikoreksi, potensial menimbulkan cedera bahu. Ahli rehabilitasi harus dapat memecah siklus penyebab cedera, dengan mendesain program rehabilitasi yang dapat mempertahankan stabilitas dinamis. Program rehabilitasi meliputi reedukasi sistem neuromuskular dan latihan untuk menciptakan keseimbangan antara agonis dan antagonis.

MEDIIORA Vol. V, No. 2, Oktober 2009: 212 - 226 
Teknik rehabilitasi bahu adalah mobilisasi jaringan lunak dan mobilisasi sendi. Pelepasan trigger point dan pemakaian es digunakan untuk memperbaiki otot-otot rotator cuff, otot scapula, dan otot-otot glenohumeral. Mobilisasi sendi digunakan untuk memperbaiki mobilitas sendi glenohumeral, sendi scapulothoracic, dan sendi clavicular. Otot-otot rotator cuff meliputi otot supraspinatus, subscapularis, teres minor, dan infraspinatus. Otot dan tendo supraspinatus bisa menjalarkan nyeri ke lengan, nyeri dirasakan sebagai nyeri dalam di sisi lateral bahu, bagian tengah otot deltoid turun ke insersi deltoid. Rasa nyeri juga bisa dijalarkan ke epicondylus lateral siku. Penyembuhan trigger point bisa dilakukan dengan posisi pasien berbaring miring atau duduk. Sisi medial trigger point biasanya lebih sensitif. Dengan posisi lengan flexi, penekanan dilakukan di atas trigger point di atas spina clavicular, sebelah lateral batas vertebra (bagian atas bahu, agak ke belakang). Pemakaian es disapukan dari insersi supraspinatus proksimal, melintasi otot dan acromion, di atas deltoid, menuju siku.

Otot subscapularis menjalarkan nyeri ke sisi posterior pergelangan tangan dan aspek inferior daerah bahu posterior, di pertemuan lengan dengan togok. Kadang nyeri juga dijalarkan ke scapula, turun ke posterior lengan, menuju siku dan mengelilingi sekitar pergelangan tangan. Pelepasan triggerpoint dilakukan dalam posisi supinasi dan lengan abduksi sekitar $60^{\circ}$ sampai $90^{\circ}$. Otot teres minor menjalarkan nyeri ke bagian posterior lengan sebelah atas, proksimal pelekatan deltoid. Nyeri dirasakan dalam dan tajam. Pelepasan triggerpoint dilakukan dalam posisi berbaring miring di sepanjang batas lateral scapula antara teres mayor inferior dan infraspinatus superior. Otot infraspinatus menjalarkan nyeri ke bagian anterior bahu, lengan, pergelangan tangan, dan sisi radial jari tangan. Pelepasan trigger point dilakukan dengan penekanan di atas otot. Otot secara progresif diregangkan dengan menggerakkan lengan ke belakang punggung dengan bahu rotasi medial.

Otot-otot scapula meliputi otot trapezius, levator scapula, serratus anterior, rhomboid, pectoralis minor, sedangkan otot-otot glenohumeral meliputi otot latissimus dorsi, teres mayor, pectoralis mayor, dan deltoid. Mobilisasi sendi dapat dilakukan pada semua sendi pada bahu. Namun perlu diketahui adanya pembatasan capsular sendi glenohumeral, yaitu gerakan abduksi lebih terbatas daripada flexi, dan flexi lebih terbatas daripada rotasi medial. Dalam melakukan 
mobilitas sendi, harus diingat bahwa permukaan humerus cembung, bergerak pada fosa glemoid yang cèkung, sehingga hukum cembung-cekung diterapkan.

Latihan fleksibilitas untuk bahu bisa berupa latihan pendulum, peregangan aktif. Peregangan tidak boleh sampai menimbulkan nyeri. Latihan fleksibilitas dilakukan pada semua penyusun sendi bahu. Latihan kekuatan untuk bahu dimulai dengan aktivitas isometrik, kemudian latihan isotonik. Latihan isometrik dimulai pada awal program rehabilitasi saat pasien terbatas mobilitas bahu dan kekuatannya. Masing-masing kontraksi isometrik secara bertahap ditingkatkan sampai kontraksi maksimum, dipertahankan, kemudian dikurangi secara bertahap sampai otot relaksasi. Tiap kontraksi isometrik dipertahankan 5 samapi 10 detik dan diulangi 10 kali. Latihan isometrik dilakukan untuk memperkuat otot-otot flexor, abduksi, ekstensor, rotasi medial, dan rotasi lateral.

Saat kekuatan otot sudah mampu mengontrol sendi selama pergerakan, latihan lebih lanjut bisa dilakukan. Jika pasien merasa nyeri saat bahu dalam posisi elevasi, sangat disarankan untuk melakukan latihan dengan tahanan manual. Pasien yang sudah mencapai kekuatan dan stabilitas bahu dapat melakukan latihan pliometrik pada permukaan yang tidak stabil, pliometrik push-up, aktivitas dengan beban, dan latihan dengan medicine-ball.

Bentuk-bentuk terapi latihan untuk cedera bahu dan lengan dapat dijelaskan sebagai berikut:

1. Codman's Pendulum Swing (Mengayun lengan)

Letakkan lengan sehat ke meja untuk menyangga tubuh. Bungkukkan badan dan biarkan lengan/bahu yang cedera menggantung rileks. Perlahan ayunkan lengan memutar searah dan berlawanan arah dengan jarum jam, kemudian ke depan-belakang dan samping-menyamping. Ulangi $30 \mathrm{kali}$ pada masing-masing arah.

2. Wall Lader (Merambat tembok)

Berdirilah menyamping tembok, jangkaulah tembok dengan lengan cedera dalam posisi lurus. Merambatlah ke atas dengan bantuan jari-jari tangan setinggi mungkin, kemudian pertahankan posisi tersebut. Ulangi 3-5 kali. Lakukan latihan ini dengan menghadap tembok maupun menyamping tembok.

3. Supine Flexion (Tekuk lengan ke belakang)

Tidur terlentang dan peganglah T-Bar atau tongkat dengan kedua tangan. 
Angkat lengan di atas kepala sejauh mungkin dan tahan 5-10 detik. Kembali ke posisi semula dan ulangi kembali gerakan ini. Apabila fleksibilitas dan kekuatan sudah bertambah, boleh ditambahkan beban pada tongkat.

4. Bent Arm Flexion (Angkat lengan ke depan-atas)

Sangga lengan yang cedera dengan tangan yang sehat, dan perlahan angkat lengan cedera tersebut kè depan dan ke atas sejauh mungkin. Pertahankan dan turunkan kembali ke posisi semula. Istirahatkan, dan ulangi gerakan ini sebanyak 30 kali.

5. T-Bar Flexion (Angkat lengan dengan T-Bar)

Pegang secara kendor ujung T-Bar dengan lengan yang cedera, dan lengan sehat memegang ujung panjang T-Bar. Angkat lengan cedera dengan mendorong T-Bar setinggi mungkin, kemudian tahan dan turunkan kembali secara perlahan. Ulangi 30 kali. T-Bar Flexion (Angkat lengan dengan T-Bar). Pegang secara kendor ujung T-Bar dengan lengan yang cedera, dan lengan sehat memegang ujung panjang T-Bar. Angkat lengan cedera dengan mendorong T-Bar setinggi mungkin, kemudian tahan dan turunkan kembali secara perlahan. Ulangi 30 kali.

6. Active Flexion (Angkat lengan Secara Aktif)

Berdirilah dengan siku lurus dan ujung jari menghadap ke depan. Angkat lengan cedera ke atas di depan tubuh setinggi mungkin, pertahankan dan turunkan secara perlahan. Ulangi gerakan ini.

7. Bent Arm Extension (Tarik lengan ke belakang-bawah)

Sangga lengan yang cedera dengan telapak tangan yang sehat, dan perlahan dorong lengan cedera ke belakang sejauh mungkin. Pertahankan, dan kemudian kembali ke posisi semula secara perlahan. Ulangi 30 kali.

8. T-BarExtension (Tarik ke belakang-bawah dengan T-Bar)

Genggam renggang ujung T-Bar dengan lengan cedera, dan pegang ujung lain dengan tangan yang sehat. Gunakan tangan sehat untuk mendorong lengan cedera ke belakang tubuh sejauh mungkin. Pertahankan dan kembalikan ke posisi awal. Ulangi 30 kali. 
9. Prone-Extension (Lengan menempel panggul)

Tidurlah telungkù dengan lengan cedera menggantung kearah lantai. Dengan lengan cedera yang diputar keluar, angkat ke belakang menuju panggul, sehingga sejajar dengan lantai. Tidak perlu lebih dari sejajar lantai.

10. Bent Arm Abduction (Angkat lengan menjauhi tubuh)

Letakkan lengan cedera di tangan yang sehat, dan dengan perlahan bawa lengan cedera menjauhi tubuh semaksimal mungkin. Pertahankan dan kembalikan pelan ke posisi semula. Rilekskan sebentar dan ulangi 30 kali.

11. T-Bar Abduction (Angkat menjauhi tubuh dengan T-Bar)

Pegang ujung T-Bar dengan lengan cedera, dan ujung lain dengan lengan sehat. Pergunakan tangan sehat untuk mengangkat lengan cedera menyamping menjauhi tubuh semaksimal mungkin. Pertahankan dan kembalikan perlahan ke posisi semula. Ulangi $30 \mathrm{kali}$.

12. Active Abduction (Angkat menjauh dari tubuh secara aktif)

Berdirilah dengan siku lurus. Angkat lengan cedera menjauhi tubuh setinggi mungkin. Pertahankan dan turunkan perlahan. Ulangi kembali.

13. Prone Horizontal Abduction (Angkat menjauhi tubuh)

Tidurlah tengkurap di meja. Angkat keluar lengan cedera menjauhi tubuh sampai sejajar lantai. Pertahankan, kembalikan ke posisi semula dan ulangi gerakan tersebut.

14. Adducted Internal / External Rotation (Memutar lengan ke dalam dan ke luar)

Dengan lengan cedera disamping badan dan menekuk siku 90 derajat, putarlah lengan menyilang tubuh ke perut sejauh mungkin. Pertahankan, kemudian ganti putar ke luar dan pertahankan. Dengan perlahan kembalikan ke posisi semula dan ulangi 30 kali.

15. Side Lying Internal Rotation (Putar lengan ke dalam dengan posisi tidur miring)

Tidurlah miring ke sisi lengan cedera dengan siku menekuk 90 derajat. Dengan perlahan, angkat tangan cedera ke perut. Pertahankan, kemudian kembalikan ke posisi semula. Ulangi beberapa kali. 
16. Side Lying External Rotation (Putar lengan ke luar dengan posisi tidur miring) Tidurlah miring ke sisi lengan yang sehat dengan siku terletak di dada dan menekuk 90 derajat. Perlahan angkat tangan ke atas menjauhi tubuh semaksimal mungkin. Pertahankan dan turunkan kembali. Ulangi gerakan ini beberapà kali.

17. Supine Internal/External Rotation (Putar lengan ke depan dan ke luar dengan posisi tidur terlentang)

Tidurlah terlentang di meja dengan bahu renggang dan siku tersangga dalam posisi menekuk. Perlahan angkat tangan ke atas dan ke depan sejauh mungkin. Pertahankan 1-2 detik, dan kembalikan ke posisi semula. Usahakan punggung tangan menyentuh meja pada posisi ke belakang dan telapak tangan menyentuh meja pada posisi ke depan. Ulangi gerakan ini beberapa kali.

18. Supraspinatus

Berdirilah dengan siku lurus dan lengan memutar ke dalam. Angkat tangan setinggi mata dengan sudut 30 derajat terhadap tubuh. Jaga jangan sampai lebih tinggi dari mata. Pertahankan, dan kembalikan ke posisi semula. Ulangi gerakan ini beberapa kali.

19. Shrugs

Berdirilah dengan lengan disamping badan. Angkat bahu ke telinga dan pertahankan. Tarik bahu ke belakang, sehingga saling mendekat. Pertahankan dan kemudian rilekskan. Ulangi beberapa kali.

20. Towel Squeeze (Memeras handuk dengan lengan atas)

Lipat handuk menjadi 1/8, kemudian letakkan diantara dada dan lengan cedera. Perlahan tekankan lengan ke handuk dan dada dengan lengan bawah menyilang di depan tubuh pada sudut 45 derajat. Pertahankan kontraksi isometrik ini 5-10 detik, kemudian rilekskan. Ulangi gerakan ini beberapa kali.

21. Supine Triceps Extension (Ekstensi trisep dalam posisi terlentang)

Berbaringlah terlentang dengan siku menekuk di dekat kepala. Letakkan lengan cedera ke bahu sehat. Perlahan luruskan siku sejauh mungkin tanpa menggerakkan lengan atas. Perlahan kembali ke posisi semula. Ulangi gerakan ini beberapa kali. 
22. Standing Triceps Press (Tekan trisep dalam posisi berdiri)

Angkat lengan cedera ke atas kepala. Sangga siku dengan lengan sehat. Perlahan luruskan lengan di atas kepala. Pertahankan dan kembalikan ke posisi semula. Ulangi beberapa kali.

23. Seated Dips

Duduklah di tepi meja atau kursi dengan tangan memegang tepian meja/ kursi. Perlahan luruskan lengan dan angkat pantat. Pertahankan 3-5 detik dan kembali ke meja dengan perlahan. Ulangi beberapa kali.

\section{ChairDips}

Letakkan bagian belakang badan di pinggiran kursi dengan kaki menjulur ke depan. Perlahan turunkan badan ke lantai sampai lengan atas sejajar lantai. Angkat badan ke atas dengan hati-hati dan pertahankan. Secara perlahan kembalilah ke posisi semula dan ulangi gerakan ini beberapa kali.

\section{Biceps Curls}

Lengan lurus disamping badan dengan tangan menghadap ke depan. Perlahan tekuklah siku kearah bahu sejauh mungkin. Pertahankan dan rilekskan ke posisi semula. Ulangi gerakan ini beberapa kali.

\section{Supine Press}

Berbaringlah terlentang dengan siku disamping dada dan menekuk 90 derajat. Perlahan angkat dan luruskan lengan ke atas. Pertahankan dan kembalikan perlahan ke posisi semula. Ulangi beberapa kali.

27. Progressive Push-Ups

Peganglah tepian tempat tidur atau meja dengan kedua kaki sejajar dan berjarak 3-4 kaki dari tempat tidur. Perlahan turunkan badan kearah tepi tempat tidur, tapi tidak sampai menyentuhnya. Kembalilah ke posisi semula dan ulangi gerakan ini. Tingkatkan dengan menggunakan tempat tidur/meja yang semakin rendah dan pada akhirnya di lantai.

28. Bent Over Rows

Bungkukkan badan sehingga sejajar dengan lantai dan lengan menggantung. Perlahan tariklah lengan ke atas sehingga tangan setinggi dada, seperti 
orang menggergaji. Turunkan dan kembali ke posisi awal. Ulangi gerakan ini beberapa kali.

\section{KESIMPULAN}

Hasil Latihan dapat dievaluasi dari adanya peningkatan fleksibilitas atau Range of Movement (ROM), kekuatan, dan daya tahan otot. Untuk unsur kekuatan dapat dinilai dari kemampuannya melawan beban, baik mendorong, menarik, mengangkat, maupun menekan. Untuk daya tahan otot dapat dinilai dari kemampuannya melakukan usaha secara berulang-ulang, sedangkan untuk fleksibilitas dinilai dari kemampuannya menusuri kisaran gerak sendi. Besarnya kisaran gerak sendi pada saat tidak cedera dapat menjadi target hasil latihan, dan secara rinci tersaji sebagai berikut: 1) Fleksi ke depan: 0 - 180 derajat, 2) Ekstensi: 0 - 70 derajat, 3) Adduksi: $0-45$ derajat

Beberapa hal yang perlu diterapkan dalam menerapkan program terapi latihan ini adalah: 1) Mulailah latihan setelah tanda radang (bengkak, merah, nyeri) mereda, 2) Terapkan Kompres panas pada lokasi cedera sebelum memulai latihan, 3) Lakukan sedikit masase sambil menerapkan kompres panas sebelum latihan, 4) Latihlah bagian cedera dengan batas rasa nyeri dan makin lama makin ditingkatkan, 5) Gunakan peralatan di sekitar yang tersedia dengan tetap berorientasi pada tujuan latihan, 6) Kompres dan gosok dengan es lokasi cedera setelah selesai latihan, dan 7) Lakukan latihan sesegera dan sesering mungkin

\section{DAFTAR PUSTAKA}

Houglum, Peggy. (2005). Therapeutic Exercise for Musculoskeletal Injuries. Second Edition. Human Kinetics.

Kannus, Pekka. (2000). Immobilization or Early Mobilization After an Acute Soft-Tissue Injury? The Physcician and Sportsmedicine, Vol. 28, No.3.

Konin, Jeff. (2009). Current Trends in Youth Sports Injuries, USF Health Orthopedic and Sports Medicine, USA.

Litbang KONI DIY. (2008). Laporan Litbang KONI DIY, Yogyakarta. 
The Athlete Project. (2005). The Injury Process. www.athleteproject.com. Diakses pada tanggal 28 Januari 2007.

Viljoen, Wayne. (2000). Principles of Rebabilitation. Diploma in Sports Management. Presentation. 